\title{
NOTES
}

\section{TINKER REVISITED: FRASER V. BETHEL SCHOOL DISTRICT AND REGULATION OF SPEECH IN THE PUBLIC SCHOOLS}

In Tinker v. Des Moines Independent Community School District ${ }^{1}$ the Supreme Court held that the first amendment protects a public school student's speech so long as the speech does not "materially and substantially" disrupt the school's operation and discipline, and does not collide with the rights of other students. Numerous students have relied on Tinker to challenge school regulations and policies. ${ }^{2}$ Fraser v. Bethel School District ${ }^{3}$ is a recent case in which a high school student relied on Tinker to challenge his suspension from high school. In Fraser, a seventeen-year-old student was suspended for delivering a crude and sexually suggestive speech ${ }^{4}$ at a high school assembly. The United States Court of Appeals for the Ninth Circuit mechamically applied Tinker and held that the student's first amendment rights were abridged because the school failed to show that the speech "materially and substantially" disrupted the school's operation. ${ }^{5}$ The Ninth Circuit concluded that "[a]s long as the speech was neither obscene nor disruptive, the First Amendment protects [the student] from pumishment by school officials."6

The Supreme Court has granted certiorari in Fraser $^{7}$ and appears ready to revisit "the area where students in the exercise of First Amendment rights collide with the rules of the school authorities." Many lower federal courts $^{9}$ have assumed that Tinker's material and substantial disruption standard is dispositive in all elementary and secondary school speech cases. Yet there are three current methods of analyzing

1. 393 U.S. 503 (1969).

2. See infra notes $34-45$ and accompanying text.

3. 755 F.2d 1356 (9th Cir.), cert. granted, 106 S. Ct. 56 (1985).

4. See infra note 48 for the entire text of Fraser's speech.

5. Fraser, 755 F.2d at $1364-65$.

6. Id. at 1365 .

7. Fraser v. Bethel School Dist., 106 S. Ct. 56 (1985).

8. Tinker, 393 U.S. at 507.

9. See infra note $32-50$ and accompanying text. 
government restrictions on speech: categorical proscription analysis, ${ }^{10}$ the public forum doctrine, ${ }^{11}$ and time, place, and manner analysis. ${ }^{12}$ This note will demonstrate that Tinker is actually a public forum doctrine case, ${ }^{13}$ with the material and substantial disruption standard representing the compelling state interest that the doctrine generally requires to justify state restriction of speech. ${ }^{14}$ By limiting analysis of school free speech cases to the Tinker standard, lower federal courts have, in essence, assumed that all such cases involve the public forum doctrine. In fact, school regulations like those in Fraser are correctly categorized as legitimate time, place, and manner restrictions. ${ }^{15}$

This note first reviews Tinker and the Ninth Circuit's application of that case in Fraser. ${ }^{16}$ After a discussion of the three forns of analysis the Court employs in free speech cases, ${ }^{17}$ the note demonstrates that Tinker is actually a public forum doctrine case. ${ }^{18}$ The note concludes that the school regulation in Fraser was a reasonable time, place, and inanner restriction that justified disciplining the student for dehivering a crude and sexually suggestive speech at the assembly. ${ }^{19}$

\section{TINKER AND THE PUBLIC SChOOLS}

A. Tinker v. Des Moines Independent Community School District.

In Tinker, the Supreme Court recognized that neither student nor teacher "shed their constitutional right to freedom of speech or expression at the schoolhouse gate."20 The dispute in Tinker arose when two high school students and one junior high school student decided to pubhcize their opposition to the Vietnam War by wearing black annbands to school. The principals of the schools became aware of the plan and adopted a policy that students wearing armbands to school would be asked to remove them; students refusing would be suspended until they returned to school without the armbands. The students were aware of the regulation, but they ignored it and were suspended. ${ }^{21}$ The Supreme

\footnotetext{
10. See infra notes $64-70$ and accompanying text.

11. See infra notes 76-82 and accompanying text.

12. See infra notes 71-75 and accompanying text.

13. See infra notes 83-95 and accompanying text.

14. See infra note 94 and accompanying text.

15. See infra notes $102-97$ and accompanying text.

16. See infra notes 20-61 and accompanying text.

17. See infra notes $62-82$ and accompanying text.

18. See infra notes 83-95 and accompanying text.

19. See infra notes $102-97$ and accompanying text.

20. Tinker, 393 U.S. at 506.

21. Id. at 504. The students sought an injunction restraining the school district from disciplining them. Tinker v. Des Moines Indep. Community School Dist., 258 F. Supp. 971, 973 (S.D. Iowa 1966). The district court dismissed the complaint on the ground that the school principals' actions
} 
Court held that the students' suspensions violated the first amendment because the school administrators failed to show that the students" "silent, passive"22 expression of opinion materially and substantially interfered with school disciphine and operation or collided with the rights of the other students. ${ }^{23}$

In reaching its conclusion, the Suprenie Court balanced the schools' concern with discipline against the students' right to freedom of expression. ${ }^{24}$ The Court rejected the district court's conclusion that school administrators acted reasonably in suspending the students because of the fear that the students wearing the armbands might cause a disturbance. The Court stated that "undifferentiated fear . . . of disturbance is not enough to overcome the right to freedoni of expression."2s

The Court offered a pedagogical rationale for prohibiting Tinkertype restrictions in the public schools. ${ }^{26}$ It examined the constitutional nature of schools, education, and students and concluded that schools are not to be "enclaves of totalitarianism"; 27 the states should not operate their schools to foster homogeneous outlooks, because the classroon is the "niarketplace of ideas" where students learn through exposure to a nultitude of views. ${ }^{28}$

Justices Black and Harlan dissented. Justice Black expressed the view that "[t]he Court's holding in this case ushers in . . . an entirely new era in which the power to control [public high school] pupils . . . is ... transferred to the Suprenie Court."29 Justice Black was concerned that the niajority opinion would enable students and teachers to use the

were constitutionally permissible because they prevented the students from disturbing school discipline. Id. The Eighth Circuit considered the case en banc and, by an equally divided court, affirmed the district court's decision without opinion. Tinker v. Des Moines Indep. Community School Dist., 383 F.2d 988 (8th Cir. 1967) (en banc).

22. Tinker, 393 U.S. at 514.

23. See id. at 513.

24. See Tinker, 393 U.S. at 506-08; see also infra note 92 and accompanying text.

25. Tinker, 393 U.S. at 508. The school admiuistrators attempted to justify the regulation on the ground that some friends of a former classmate who was killed in Vietnam might confront the students and cause a disturbance. Id. at 509 n.3.

26. See Diamond, The First Amendment and Public Schools: The Case Against Judicial Intervention, 59 TEX. L. REV. 477, 480 (1981).

27. The Court stated:

Iu our system, state-operated schools may not be enclaves of totalitarianism. School authorities do not possess absolute authority over their students. Students in school as well as out of school are "persons" under our Constitution. They are possessed of fundamental rights which the State must respect, just as they themselves must respect their obligations to the State. In our system, students may not be regarded as closed-circuit recipients of only that which the State chooses to communicate. They may not be confined to the $\mathrm{cx}$ pression of those sentiments that are officially approved.

Tinker, 393 U.S. at 511.

28. Id. at 512 .

29. Id. at 515 (Black, J., dissenting). 
school as a platform to air their beliefs at the expense of other students' education. ${ }^{30}$ Justice Harlan agreed that the first and fourteenth amendments governed the conduct of the school administrators; however, he proposed that students should have the burden of showing that a particular school rule was not motivated by legitimate school concerns. ${ }^{31}$

\section{B. Tinker's Progeny: Fraser v. Bethel School District.}

Justice Black's fear that Tinker ushered in a "new era" in which courts would play a significant role in school discipline was well founded. ${ }^{32}$ Since Tinker, hundreds of cases have been brought by students alleging violations of their constitutional rights. ${ }^{33}$ Students have used Tinker and the Constitution to cliallenge tlie actions of public scliool autliorities concerning dances, ${ }^{34}$ demonstrations, ${ }^{35}$ discipline, ${ }^{36}$ student body elections, ${ }^{37}$ school searches, ${ }^{38}$ liair length, ${ }^{39}$ library books, ${ }^{40}$

30. See id. at 517, 522 (Black, J., dissenting).

31. Id. at 526 (Harlan, J., dissenting).

32. See Goss v. Lopez, 419 U.S. 565, 600 n.22 (1975) (Powell, J., dissenting) (asserting that Justice Black's prophecy in Tinker was being fulfilled).

33. Id; see also infra notes $34-45$ and accompanying text.

34. See Fricke v. Lynch, 491 F. Supp. 381, 387 (D.R.I. 1980) (school officials demied first amendment rights of homosexual student when they refused to allow him to bring male escort to prom).

35. See Pickens v. Okolona Mun. Separate School Dist., 594 F.2d 433, 437 (5th Cir. 1979) (sustaining injunction against desegregation demonstrations conducted by students and parents on property adjacent to high school on ground that protests imterfered with school's operations); Karp v. Becken, 477 F.2d 171, 176 (9th Cir. 1973) (high school student could not be suspended for carrying sign to protest firing of teacher); Garvin v. Rosenau, 455 F.2d 233, 240 (6th Cir. 1972) (reversing dismissal of complaint brought by high school student against principal who refused to allow students to protest Vietnam War during school); Hatter v. Los Angeles City High School Dist., 452 F.2d 673, 674-75 (9th Cir. 1971) (reversing dismissal of high school student's complaint that suspension for passing out leaflets violated first amendment).

36. See Ingraham v. Wright, 430 U.S. 651, 664 (1977) (cruel and unusual punishment clause of eighth amendment does not apply to corporal punishment in public secondary schools); Goss v. Lopez, 419 U.S. 565, 579 (1975) (procedural due process requires that public secondary school students have some type of hearing prior to suspension or expulsion); Hall v. Tawney, 621 F.2d 607, 611 (4th Cir. 1980) (substantive due process rights might be implicated in school disciplinary punishment); Boykins v. Fairfield Bd. of Educ., 492 F.2d 697, 701-02 (5th Cir. 1974) (due process does not preclude principal froin basing expulsions on hearsay), cert. denied, 420 U.S. 962 (1975). See generally Rossow, Administrative Discretion and Student Suspension: A Lion in Waiting, 13 J.L. \& EDuc. 417 (1984); Teitelbaum, School Discipline Procedures: Some Empirical Findings and Some Theoretical Questions, 58 IND. L.J. 547 (1983).

37. See Palacios v. Foltz, 441 F.2d 1196, 1198 (10th Cir. 1971) (student does not have constitutional right to run for co-president of student council).

38. Cf. New Jersey v. T.L.O., $105 \mathrm{~S}$. Ct. 733, 739 (1985) (fourth amendment applies to unreasonable searches and seizures conducted by public school officials).

39. The First, Fourth, Sixth, Seventh, and Eighth Circuits have stated that federal courts should provide a judicial forum in school hair-length cases. See Holsapple v. Woods, 500 F.2d 49, 51-52 (7th Cir.) (per curiam), cert. denied, 419 U.S. 901 (1974); Massie v. Henry, 455 F.2d 779, 783 (4th Cir. 1972); Bishop v. Colaw, 450 F.2d 1069, 1075 (8th Cir. 1971); Richards v. Thurston, 424 
movies, ${ }^{41}$ school plays, ${ }^{42}$ prayer meetimgs, ${ }^{43}$ textbook selection, ${ }^{44}$ and school newspapers. ${ }^{45}$

Fraser v. Bethel School District ${ }^{46}$ is a recent case in which a student

F.2d 1281, 1284 (1st Cir. 1970); Jackson v. Dorrier, 424 F.2d 213, 218-19 (6th Cir.), cert. denied, 400 U.S. 850 (1970). The Third, Fifth, Ninth, and Tenth Circuits have stated that federal courts should not provide a judicial forum in school hair-length cases. See Zeller v. Donegal School Dist. Bd. of Educ., 517 F.2d 600, 605-06 (3d Cir. 1975); Hatch v. Goerke, 502 F.2d 1189, 1192 (10th Cir. 1974); Karr v. Schmidt, 460 F.2d 609, 611 (5th Cir.) (en banc), cert. denied, 409 U.S. 989 (1972); Freeman v. Flake, 448 F.2d 258, 261-62 (10th Cir. 1971), cert. denied, 405 U.S. 1032 (1972); King v. Saddleback Jr. College Dist., 445 F.2d 932, 940 (9th Cir. 1971) (two cases consolidated at court of appeals level), cert. denied, 404 U.S. 979 (1971) and cert. denied sub nom. Olff v. East Side Union High School Dist., 404 U.S. 1042 (1972).

40. See, e.g., Board of Educ. v. Pico, 457 U.S. 853, 871 (1982) (plurality opinion) (whether school board's removal of books from public sehool library comports with first amendment depends on the school board's motive for removing books).

41. See Pratt v. Independent School Dist. No. 831, 670 F.2d 771, 776-79 (8th Cir. 1982) (school board's removal of film to suppress ideological or religious viewpoint with which school board disagreed violated students' first amendment rights).

42. See Seyfried v. Walton, 668 F.2d 214, 217 (3d Cir. 1981) (school superintendent's decision to cancel high school production of play because of its sexual theme did not violate students' first amendment right of expression).

43. See, e.g., Bender v. Williamsport Area School Dist., 741 F.2d 538, 561 (3d Cir. 1984) (student-organized rehigious group could not meet during a student activity hour), cert. granted, $105 \mathrm{~S}$. Ct. 1167 (1985); Lubbock Civil Liberties Union v. Lubbock Indep. School Dist., 669 F.2d 1038, 1048 (5th Cir. 1982) (school district policy permitting voluntary prayer groups violates establishment clause), cert. denied, 459 U.S. 1155 (1983); Brandon v. Board of Educ., 635 F.2d 971, 979-80 (2d Cir. 1980) (school board's refusal to allow prayer sessions before classes did not violate students' right to free speech), cert. denied, 454 U.S. 1123 (1981). See generally Strossen, A Framework for Evaluating Equal Access Claims by Student Religious Groups: Is There a Window for Free Speech in the Wall Separating Church and State?, 71 CORNELl L. REv. 143 (1985); Note, Religious Expression in the Public School Forum: The High School Student's Right to Free Speech, 72 GEO. L.J. 135 (1983); Note, The Constitutional Dimensions of Student-Initiated Religious Activity in Public High Schools, 92 YALE L.J. 499 (1983).

44. See Johnson v. Stuart, 702 F.2d 193, 195-96 (9th Cir. 1983) (high school students have standing to challenge Oregon textbook selection statute that allegedly restricts first amendment rights); Loewen v. Turnipseed, 488 F. Supp. 1138, 1153-54 (N.D. Miss. 1980) (students' and school administrators' successful challenge of Mississippi's textbook "rating committee" decision not to purchase book).

45. See, e.g., Gambino v. Fairfax County School Bd., S64 F.2d 157, 158 (4th Cir. 1977) (per curiam) (high school newspaper protected by first amendment); Trachtman v. Anker, 563 F.2d 512, 519-20 (2d Cir. 1977) (students' first amendment rights to publish sex questionnaire subordinate to school administrator's power), cert. denied, 435 U.S. 925 (1978); Shanley v. Northeast Indep. School Dist., 462 F.2d 960, 975-76 (5th Cir. 1972) (school rule requiring prior submission and approval of newspaper declared facially unconstitutional as overbroad because it allowed administrators to impose prior restraints for any reason); Scoville v. Board of Educ., 425 F.2d 10, 13-15 (7th Cir. 1970) (en banc) (expulsion of student newspaper writers for criticizing school policies and authorities violates students' first amendment rights), cert. denied, 400 U.S. 826 (1970). See generally Huffman \& Trauth, High School Students' Publication Rights and Prior Restraint, 10 J.L. \& EDuc. 485 (1981); Nichols, Vulgarity and Obscenity in the Student Press, 10 J.L. \& Educ. 207 (1981); Note, Administrative Regulation of the High School Press, 83 Mich. L. REv. 625 (1985).

46. 755 F.2d 1356 (9th Cir.), cert. granted, 106 S. Ct. 56 (1985). 
relied on Tinker to challenge a school regulation. ${ }^{47}$ At a school assembly, Matthew Fraser, a seventeen-year-old high school student, nominated a friend and classmate for school office by delivering a crude and sexually suggestive speecl. 48

The day after the speecli, the assistant principal cliarged Fraser witl violating the school's disruptive conduct rule. ${ }^{49} \mathrm{He}$ was suspended for tluree days, and his name was removed from the list of eligible graduation speakers. When the superintendent of the scliool district demed Fraser's appeal, Fraser filed a lawsuit alleging that the scliool liad violated his first amendment rights. The district court rehed on Tinker's material and substantial disruption standard and held for Fraser, declaring his pumshment null and void, and awarding him damages, costs, and attorney's fees. ${ }^{50}$

On appeal to tlie Ninth Circuit, the scliool district presented three arguments to support its claim that the disciplinary action did not abridge Fraser's constitutional riglits: (1) Fraser's speech materially and substantially disrupted the school's educational process; (2) Fraser's imdecent language justified the disciplinary actions; and (3) the scliool district could discipline Fraser for the objectionable language because Fraser made the speech at a scliool-sponsored function. ${ }^{51}$ The court of appeals considered and rejected eacli argument.

The court found that the scliool district's evidence failed to establish that Fraser's speecli materially and substantially interfered witl the educational process. That evidence consisted of the testimony of school counselors and teacliers that one student in the bleachers simulated masturbation, two others simulated sexual intercourse, some students liooted

47. The rule, which was pubhished in the school's student handbook, stated:

In addition to the criuninal acts defined above, the commission of, or participation in certain noncriminal activities or acts may lead to disciplinary action. Generally, these are acts which disrupt and interfere with the educational process.

Disruptive Conduct. Conduct which inaterially and substantially interferes with the educational process is prohibited, including the use of obscene, profane language or gestures.

Fraser, 755 F.2d at 1357 n.1.

48. The following is the entire text of Fraser's nominating speech:

I know a man who is firm-he's firm in his pants, he's firm in his shirt, his character is firm-but most of all his belief in you, the students of Bethel is firm. Jeff Kuhlman is a man who takes his poimt and pounds it in. If necessary, he'll take an issue and nail it to the wall. He doesn't attack things in spurts-he drives hard, pushing and pushing and pushing until finally-he succeeds. Jeff is a man who will go to the very end-even the climax, for each and every one of you. So vote for Jeff for ASB vice-president-he'll never come between you and the best our high school can be.

Fraser, 755 F.2d at 1357.

49. See supra note 47 and accompanying text.

50. Fraser v. Bethel School Dist., No. C83-306T (W.D. Wash. June 8, 1983), aff'd, 755 F.2d

1356 (9th Cir.), cert. granted, 106 S. Ct. 56 (1985).

51. Fraser, 755 F.2d at 1358-59. 
and hollered, and other students acted shocked and embarrassed.52 It included complaints by several teachers that student discussion of Fraser's speech had disrupted their classes the next day and written statements submitted by other teachers complaining that Fraser's speech was inappropriate for a school assembly. ${ }^{53}$ The court of appeals, however, held that the school district had failed to distinguish the disruption in Tinker from the disruption caused by Fraser's speech..$^{54}$

The court of appeals also rejected the school district's argument that Fraser's indecent language justified the disciplinary action. The school relied on FCC v. Pacifica Foundation ${ }^{5 s}$ to argue that school officials had a legitmiate interest im protecting teachers and students from offensive and indecent speech, and that this interest outweighed Fraser's interest in usmg sexual innuendo. ${ }^{56}$ In Pacifica Foundation the Supreme Court held that the imposition of administrative sanctions by the Federal Communications Commission (FCC) on a radio station for broadcasting George Carlin's "Filthy Words" monologue ${ }^{57}$ did not violate the first amendment, even though the broadcast was only indecent, and not obscene. 58 The court of appeals distinguished Pacifica Foundation and concluded that it did not apply to the high school assembly. ${ }^{59}$

Finally, the court of appeals rejected the school district's third argument-that school officials could control the language used to convey ideas at scliool-sponsored events. The school district relied on cases allowing school officials to control students' language at school-sponsored

52. Id. at 1366 (Wright, J., dissenting).

53. Id. (Wright, J., dissenting).

54. Id. at 1359-61.

55. 438 U.S. 726 (1978).

56. Fraser, 755 F.2d at 1361 .

57. For a complete text of the monologue, see Pacifica Found., 438 U.S. at 751-55.

58. Id. at 748-51.

59. Fraser, 755 F.2d at 1361-63. The Fraser court described the Court's decision in Pacifica Foundation as resting on two principal rationales. First, "broadcasting intrudes directly on the privacy of an unwilling listener while he or she is at home"; and second, "broadcasting is uniquely available to unsupervised children, even those too young to read." Id. at 1362. The court of appeals concluded that Pacifica's first reason-that broadcasting can be very intrusive upon the privacy of the home-simply did not apply to a high school assembly. The court of appeals asserted that students at a high school assembly could not expect the same measure of privacy and protection from unwelcome language and ideas that they enjoyed at home. Id. The court also concluded that Pacifica's second reason-that broadcasting was accessible to impressionable young children-was also inapplicable to a high school assembly. The Court stated: "[r]ealistically, high school students are beyond the point of being sheltered from the potpourri of sights and sounds we encounter at every turn in our daily lives. Although we may be offended by what we see and hear, that is a price we pay for the privilege of living in a free and open pluralistic society." Fraser, 755 F.2d at 1363. The court of appeals incorrectly analyzed these two rationales. See infro notes 128-33 and accompanying text. 
functions. ${ }^{60}$ The court of appeals distinguished these cases and held that "as long as the speech was neither obscene nor disruptive, the First Amendment protects [Fraser] from punishment by school officials." 61

\section{Regulation of SPEech AND the First AMENDMENT}

In Fraser, the Suprenie Court is again faced with a first amendment case that focuses on the scope of governmental power to regulate speech. ${ }^{62}$ The Court has developed three analytic frameworks applicable

60. The court of appeals cited Nicholson v. Board of Educ., 682 F.2d 858 (9th Cir. 1982); Seyfried v. Walton, 668 F.2d 214 (3d Cir. 1981); Trachtman v. Anker, 563 F.2d 512 (2d Cir. 1977), cert. denied, 435 U.S. 925 (1978). Fraser, 755 F.2d at 1363-65. For a discussion of these cases, see infra note 61 .

61. Fraser, 755 F.2d at 1363-65. The school district argued that it had greater discretion to control the content of the school curriculum and relied on Board of Educ. v. Pico, 457 U.S. 853 (1982), to support this proposition. The court of appeals found this reliance "puzzling," Fraser, 755 F.2d at 1364, because the court thought that Pico stood for the proposition that school administrators could control the content of the discussion in the classroom but could not extend their discretion beyond the classroom into the library. Id. The Fraser court concluded that the student assembly was even further removed from the classroom environment than was a library; therefore, Pico did not apply and did not support the proposition that the school administrators could control sexually offensive and vulgar speech. Id.

The Ninth Circuit's analysis of Pico misses two important points. First, in Pico the Court recognized that school administrators could remove books from the library that were vulgar so long as the school administrators were not seeking to suppress a particular viewpoint. Pico, 457 U.S. at 871 . Second, the Ninth Circuit ignored the difference between a high school student who goes to a library and chooses to read a book containing profanity or other vilgar speech, and school children who attend a high school assembly without any warning that they will be forced to listen to sexually vulgar and indecent speech. The child in the captive audience at the school assembly is in a very different position from that of the child in the library. See infra notes 113-23 and accompanying text.

The school district also cited Seyfried v. Walton, 668 F.2d 214, 217 (3d Cir, 1981), where the Third Circuit held that a school administrator's decision to cancel a drama class production of "Pippin" because of its sexual content did not violate the first amendment. The Fraser court distinguished Seyfried because it believed that the play was part of the curriculum while the school assembly was not. Fraser, 755 F.2d at 1364-65. The court also distinguished Nicholson v. Board of Educ., 682 F.2d 858, 863 (9th Cir. 1982), where the court held that prepublication review of a student newspaper published as part of a journalism class did not violate the first amendment because the journalism class was part of the curriculum. Fraser, 755 F.2d at 1363-64. The Fraser court misunderstood and misapplied the definition of curriculum. See infra notes 137-42 and accompanying text.

The court of appeals also distinguished Trachtman v. Anker, 563 F.2d 512, 519 (2d Cir. 1977), where the Second Circuit held that school officials could restrain student efforts to distribute a sex questionnaire. The Fraser court argued that the school officials in Trachtman had made an adequate showing that distribution of the questionnaire would result in emotional harm to students, but that the school administrators in Fraser had failed to make a similar showing. Fraser, 755 F.2d at 1365.

62. Public school authorities' actions are subjeet to the limitations placed on state action by the fourteenth amendment. See, e.g., New Jersey v. T.L.O., 105 S. Ct. 733, 739-41 (1985) (school teachers and school principal); Cooper v. Aaron, 358 U.S. 1, 16 (1958) (members of school board and superintendent of schools); West Virginia State Bd. of Educ. v. Barnette, 319 U.S. 624, 637 (1943) (members of board of education). 
to government restrictions on speech: categorical proscription analysis; traditional time, place, and manner analysis; and the public forum doctrine. ${ }^{63}$

\section{A. Categorical Proscription.}

The Court has allowed content regulation in the form of categorical proscription of certain types of speech. ${ }^{64}$ The current categories of speech that the government can proscribe include: (1) speech that creates a clear and present danger of illegal behavior, particularly of physical violence; ${ }^{65}$ (2) defamation; ${ }^{66}$ (3) false or misleading commercial speech; ${ }^{67}$ (4) child pornography; ${ }^{68}$ and (5) obscenity. ${ }^{69}$ Any contentbased statute or regulation that proscribes speech falling outside these articulated categories will be declared unconstitutional. ${ }^{70}$

\section{B. Time, Place, and Manner Restrictions.}

The Court has used time, place, and manner analysis to assess the constitutionahty of incidental restrictions on speech. ${ }^{71}$ Tine, place, and

63. Professors Farber and Nowak have defined the three analytic frameworks and discussed them extensively. See Farber \& Nowak, The Misleading Nature of Public Forum Analysis: Content and Context in First Amendment Adjudication, 70 VA. L. REv. 1219, 1220-39 (1984).

64. Id. at $1226-30$.

65. See Cohen v. California, 403 U.S. 15, 20 (1971) (words "inherently likely to provoke violent reaction") (eiting Chaplinsky v. New Hampshire, 315 U.S. 568, 573 (1942)); Brandenburg v. Ohio, 395 U.S. 444, 447 (1969) (per curiam) (words directed towards inciting "imminent lawless action," and likely to have such effect); see also Gooding v. Wilson, 405 U.S. 518, 523 (1972) ("offensive, derisive, or annoying" words; subsequently narrowed by judicial construction to "fighting" words); Feiner v. New York, 340 U.S. 315, 320-21 (1951) (hostile audience).

66. See Gertz v. Robert Welch, Inc., 418 U.S. 323, 340 (1974); New York Tiines Co. v. Sullivan, 376 U.S. 254, 268 (1964).

67. See Central Hudson Gas \& Elec. Corp. v. Public Serv. Comm'n, 447 U.S. 557, 563-66 (1980).

68. See New York v. Ferber, 458 U.S. 747, 763-64 (1982).

69. See Paris Adult Theatre I v. Slaton, 413 U.S. 49, 54 (1973); Miller v. California, 413 U.S. 15, 23 (1973).

70. See Farber \& Nowak, supra note 63, at 1229.

71. See, e.g., Consolidated Edison Co. v. Public Serv. Coinın'n, 447 U.S. 530, $535-37$ (1980) (Public Service Comınission's order prohibiting Consolidated Edison from using utility bill inserts to discuss political matters was not a valid time, place, and manner regulation because Cominission allowed inserts on certain subjects but prohibited inserts on matters of public controversy); Lininark Assocs. v. Township of Willingboro, 431 U.S. 85, 90-91, 93 (1977) (township ordinance prohibiting the posting of real estate "For Sale" and "Sold" signs in order to eurtail "white flight" was not a valid time, place, and manner regulation because it failed to leave open ample alternative channels of cominunication and sought to suppress only signs with particular content); Virginia Statc Bd. of Pharmacy v. Virginia Citizens Consumer Council, Inc., 425 U.S. 748, 771 (1976) (state statute prohibiting prescription price advertising was not a valid time, place, and inanner regulation because it singled out speech of particular content and sought to prohibit it completely); Grayned v. City of Rockford, 408 U.S. 104, 115, 118-21 (1972) (city's anti-noise ordinance prohibiting picketing that is disruptive or incompatible with nomal school activities was valid time, place, and manner regula- 
manner regulations aim at restricting the physical inanner, location, or time of the speech commumication, not what is being said. ${ }^{72}$ The Court has recognized that the government can innpose reasonable tinne, place, and manner regulations on speech so long as the regulations (1) are content-neutral,,$^{73}$ (2) serve a significant governmental interest, and (3) leave open adequate alternative channels of communication. ${ }^{74}$ In addition, the Court will scrutinize an alleged time, place, and manner regulation to ensure that it is not vague or overbroad. If the regulation fails to meet any of the three criteria or is vague or overbroad, the Court will declare the regulation an unconstitutional restriction of speech. ${ }^{75}$

\section{The Public Forum Doctrine.}

The final analytic framework that the Court has developed is the public forum doctrine. ${ }^{76}$ The Court established the public foruin doctrine as a inethod of determining when the government's interest in limiting the use of its property to its intended purpose outweighs the interest of those wishing to use the property to exercise their right to freedoin of speech. ${ }^{77}$ The Constitution does not require the government to grant access to all those wishing to exercise their right to freedom of speech on government property. The Court has defined three types of forums-the quintessential public fornm, the limited public foruin, and the nonpublic forum-as a means of analyzing content-related regulations. ${ }^{78}$

tion since ordinance only punished picketing that disrupted school's normal activities); Cox v. New Hampshire, 312 U.S. 569, 575-76 (1941) (state statute prohibiting parades on public streets without licenses is valid time, place, and manner regulation since statute's purpose is to prevent confusion and disorder on public streets irrespective of content of parader's message).

72. See, e.g., Farber \& Nowak, supra note 63, at 1237.

73. But see infra note 105 and accompanying text.

74. See, e.g., Clark v. Community for Creative Non-Violence, 104 S. Ct. 3065, 3067 (1984), in which the Court held that the National Park Service could refuse permission for a round-the-clock denionstration in a Washington, D.C. park. The demonstrators wished to sleep in symbolic "tent cities" in the park to call attention to the plight of the homeless. Id. at 3068. The Court found that the Park Service regulation prohibititing such demonstrations was a valid time, place, and manner regulation beeause (1) it was a content-neutral means of pronoting the government's substantial interest in preserving park lands, and (2) it allowed adequate alternative channels of communication because the government did not prohibit the demonstrators from using their signs protesting the plight of the hoineless to maintain an all-night vigil in the park. Id. at 3070; see also Heffron v. International Soc'y for Krishna Consciousness, 452 U.S. 640, 654-55 (1981) (same criteria employed in upholding a state regulation prohibiting sales and distributions of any merchandise except in licensed location on fairgrounds).

75. See J. NowaK, R. Rotunda \& J. Young, Constitutional Law 977-79 (2d ed. 1983).

76. The article by Professors Farber and Nowak, supra note 63, at $1240-43$, persuasively argues that the Court should abandon the public forum doctrine in favor of a "focused balancing" test.

77. See, e.g., Cornelius v. NAACP Legal Defense \& Educ. Fund, 105 S. Ct. 3439, 3448 (1985).

78. See, e.g., Perry Educ. Ass'n v. Perry Local Educators' Ass'n, 460 U.S. 37, 45-48 (1983). 
Quintessential public forums are places, such as public parks or streets, that by long tradition or by government fiat have been devoted to assembly and debate. ${ }^{79}$ In the quimtessential public forum the government must show that its content-based regulation is necessary to serve a compelling state interest and is narrowly drawn to achieve that end. ${ }^{80}$ Limited public forums are public properties that the government has opened for use by the public as places for expressive activity. As in the case of quintessential public forums, the Court applies the compelling state interest standard when content-related regulations are imposed on speech in a limited public forum; in contrast to the governinent's inability to foreclose use of the quintessential public forum, however, the government may close the limited forum altogether without violating the first amendment. ${ }^{81}$ Nonpublic forums are public properties that are not by tradition designated as forums for public commurrication. In a nonpublic forum the governinent inay prohibit speech on the basis of content so long as the goverument has a rational basis and is acting in a viewpoint-neutral manner. ${ }^{82}$

\section{TINKER AND THE PUblic Forum Doctrine}

Many lower federal courts have assumed that Tinker's inaterial and substantial disruption standard is controlling on all questions of student speech in the public secondary and elementary schools. ${ }^{83}$ By not examining the validity of this assumption, however, the lower federal courts have failed to recognize that Tinker represents only one of the three current modes of analysis that the Court uses in assessing restrictions on speecl1-the public forum doctrine. In part, this failure stems from the

79. This notion is eloquently expressed in Justice Roberts's oft-quoted dictum in Hague v. CIO, 307 U.S 496, 515 (1939):

Wherever the title of streets and parks may rest, they have immemorially been held in trust for the use of the public and, time out of mind, have been used for purposes of assembly, communicating thoughts between citizens, and discussing public questions. Such use of the streets and public places has, from ancient times, been a part of the privileges, immunities, rights, and liberties of citizens.

80. Perry Educ. Ass'n v. Perry Local Educators' Ass'n, 460 U.S. 37, 45 (1983).

81. See, e.g., Widmar v. Vincent, 454 U.S. 263, 267-68 \& n.5 (1981) (university meeting facilities); City of Madison Joint School Dist. v. Wisconsin Employment Relations Comm'n, 429 U.S. 167, 175 \& n.8 (1976) (school board meeting); Southeastern Promotions, Ltd. v. Conrad, 420 U.S. 546, 555-59 (1975) (municipal theater).

82. See, e.g., Cornelius v. NAACP Legal Defense and Educ. Fund, 105 S. Ct. 3439, 3450-51, 3454 (1985) (charity drive aimed at federal employees); Perry Educ. Ass'n v. Perry Local Educators' Ass'n, 460 U.S. 37, 46 (1983) (school mail facilities); United States Postal Serv. v. Council of Greenburgh Civic Ass'ns, 453 U.S. 114, 129-31 (1981) (mailboxes of private homes); Jones v. North Carolina Prisoners' Labor Union, 433 U.S. 119, 134 (1977) (prison); Greer v. Spock, 424 U.S. 828, 838 n.10 (1976) (military base); Lehman v. City of Shaker Heights, 418 U.S. 298, 304 (1974) (plurality opinion) (commercial advertising space on city buses).

83. See supra notes $32-46$ and accompanying text. 
fact that the decision preceded the formal articulation of the public forum doctrine. In any case, by limiting the inquiry in school free speech cases to the Tinker analysis, it is obvious that many lower courts have, in effect, conducted an incoinplete analysis of the first amendinent dimensions of challenged regulations.

The public forum doctrine is used to deterinine when the government's interest in himiting the use of its property to its intended purpose outweighs the interest of the speaker who wishes to exercise his right to freedom of speech. ${ }^{84}$ The doctrine examines the nature of the public property and evaluates the property's compatibility with expressive activity. ${ }^{85}$

Under current pubhic foruin doctrime analysis, courts are first required to define the appropriate forum and then to determine whether it is a quintessential public, limited public, or nonpublic forum. ${ }^{86}$ When the expressive activity is incompatible with the property's purpose-determined by the categorization of the property as quintessentially public,

84. See, e.g., Cornelius v. NAACP Legal Defense \& Educ. Fund, 105 S. Ct. 3439, 3448 (1985).

85. See, eg., id. at 3449; Perry Educ. Ass'n v. Perry Local Educators' Ass'n, 460 U.S. 37,49 n.9 (1983); United States Postal Serv. v. Council of Greenburgh Civic Ass'ns, 453 U.S. 114, 130 n.6 (1981) (residential mailbox is nonpublic forum and delivering unstamped messages in residential mailboxes is basically incompatible with maintenance of safe and efficient mail systems); Greer $v$. Spock, 424 U.S. 828, 842-43 (1976) (Powell, J., concurring) (military base is nonpublic forum, and political rallies are basically incompatible with normal activity of military base).

86. In Cornelius v. NAACP Legal Defense and Educ. Fund, 105 S. Ct. 3439 (1985), the NAACP Legal Defense Fund, the Sierra Club Legal Defense Fund, and others (the "plaintiffs") challenged their exclusion from the Combimed Federal Campaign (CFC), a charity drive aimed at federal employees. By executive order the CFC is limited to voluntary, tax-exempt, nonprofit cliaritable agencies that provide direct health and welfare services to individuals. Exec. Order No. 12404, 3 C.F.R. 151 (1984). The executive order specifically excludes legal defense and political advocacy organizations. The plaintiffs challenged their exclusion on the grounds that the denial of the right to seek CFC funds violated their first amendment right to solicit charitable contributions. Cornelius, 105 S. Ct. at $3443-47$.

The Court stated that it had to define the relevant forum before determining whether the forum was public or nonpublic. The goverument argued that the only government property involved was the federal workplace; therefore, the Court's public forum doctrine should focus on tire federal workplace. The plaintiffs argued that the fornm should be defined in terms of the access sought by the speaker. Under their view, the particular channel of communication constituted the forum; therefore, they argued that because they only sought access to the CFC, the CFC should be the relevant forum for first amendment purposes. Id. at 3448-49.

The Court agreed with the plaintiffs that the CFC was the proper forum. In defining the forum, the Court announced that the proper focus was on the access sought by the speaker. When speakers seek general access to public property, as in Greer v. Spock, 424 U.S. 828, 832 (1976), where Dr. Spock sought access to the military base in order to hold a political rally, the forum encompasses that property. In cases of limited access, however, such as the plaintiffs' access to the CFC, the Court stated that a more tailored approach was appropriate in defining the forum. Cornelius, $105 \mathrm{~S}$. Ct. at 3449; see also Perry Educ. Ass'n v. Perry Local Educators' Ass'n, 460 U.S. 37, 44-46 (1983) (school mail facility, not entire school, was the proper forum); Widmar v. Vincent, 454 U.S. 263, 267-68, 267 n.5 (1981) (university meeting facility, not entire university, was the proper forum). 
limited public or nonpublic - the government may restrict speech without violating the first amendment. 87

In Tinker, the Supreme Court did not expressly rely on public forum doctrine analysis. The doctrine, in fact, was in a nascent stage and had not been articulated as a distinct inode of analysis. ${ }^{88}$ Nonetheless, the basic elements of what would come to be called "public forum doctrine" analysis were present in the Tinker decision. The Tinker Court began by defining an entire secondary scliool campus as an appropriate forum and concluded that a campus constituted a linited public forum..$^{89}$ The Court expressly refused to conclude that a public secondary school should be treated as a prison, ${ }^{90}$ which, under current doctrine, is a nonpublic forum. ${ }^{91}$ Instead, the Court balanced the students' first amendment riglits against the schools' need for order and discipline, ${ }^{92}$ in the same mamier in which the current public forum doctrine weighs the government's intended purpose against the interest of the speaker in exercising his right to freedom of speecl1. ${ }^{93}$ The material and substantial disruption standard is, thus, but one manifestation of a state interest sufficiently compelling under current limited public forum analysis to justify a restriction on speech and simply represents a conclusion that speech that materially and substantially disrupts the educational process is incompatible witl1 the secondary and elementary school environment. ${ }^{94}$

Recognition that Tinker is simply a public forum decision compels the conclusion that the material and substantial disruption standard is not dispositive on all questions of student speech; rather, it constitutes

87. See supra note 85 and accompanying text.

88. See Farber \& Nowak, supra note 63, at 1221 (public forum doctrine received attcntion twenty years ago, "but it was almost never used in Supreme Court opinions until recently").

89. See Tinker, 393 U.S. at 508 ("no threats or acts of violence on the school premises"); id. at 512-13 (Tinker does not merely apply to the classroom, but to the campus during school's authorized hours).

90. See id. at 512 n.6; $c f$ New Jersey v. T.L.O., 105 S. Ct. 733, 742 (1985) (refusing to equate schools and prisons for fourth amendment purposes).

91. See, e.g., Jones v. North Carolina Prisoners' Union, 433 U.S. 119, 125 (1977); Pell v. Procunier, 417 U.S. 817, 822 (1974); Procunier v. Martinez, 416 U.S. 396, 404-05 (1974).

92. See Tinker, 393 U.S. at 507 ("Our problem lies in the area where students in the exercise of First Amendment rights collide with rules of school authorities."); see also infra note 165 and accompanying text.

93. See supra note 84 and accompanying text.

94. See, e.g., Cornelius v. NAACP Legal Defense \& Educ. Fund, 105 S. Ct. 3439, 3456, 3461 n.3 (1985) (Blackmun, J., dissenting); United States v. Grace, 461 U.S. 171, 184-85 (1983) (Marshall, J., concurring in part and dissenting in part) (citing Tinker for the proposition that speech must not be incompatible with the primary activity of the school); United States Postal Serv. v. Council of Greenburgh Civic Ass'ns, 453 U.S. 114, 137 (1981) (Brennan, J., concurring in judgment) (citing Tinker for the proposition that "public properties are the appropriate fora for First Amendment rights"); Grayned v. City of Rockford, 408 U.S. 104, 118 (1972) ("Tinker made clear that school property may not be declared off limits for expressive activity by students."). 
only one level of inquiry, and, as a result, lower courts are further required to determine whether the school can present some other compelling interest, ${ }^{95}$ or whether a student's speech falls into a category that can be prohibited, or whether a school regulation of speech can be sustained as a reasonable time, place, and manner regulation.

\section{FRASER RECONSIDERED}

The Ninth Circuit in Fraser v. Bethel School District adopted the widespread but erroneous assumption that Tinker was dispositive in student speech cases. ${ }^{96} \mathrm{Had}$ the court of appeals examined Matthew Fraser's speech under all three methods of analyzing speech restrictions, it would not have deemed his pumishment unconstitutional.

\section{A. Categorical Proscription.}

Categorical proscription analysis would not have changed the result in Fraser. The only category that the court might have considered was obscenity. The school authorities conceded, however, that Fraser's speech was not obscene. ${ }^{97}$ Unless the Supreme Court extends categorical proscription to include indecent speech, which it previously failed to do in FCC v. Pacifica Foundation, ${ }^{98}$ Fraser's speech would remain protected under this mode of analysis.

\section{B. Public Forum Doctrine.}

The court of appeals never expressly mentioned the public forum doctrine in its analysis of Fraser's speech. The court did, however, reject the argument that Fraser's speech at the scliool assembly was part of the curriculum, thereby allowing the scliool admimistrators greater discretion in regulating the speech. ${ }^{99}$ Moreover, the court declared that the school created an "open forum" 100 by allowing Fraser to speak. By rejecting the argument that the school assembly was part of the curriculum and declarmg that the scliool created an "open forum," the court seems to have

95. For example, some courts have held that the interest in protecting free speech within the context of student activity periods for student-initiated religious groups is outweighed by establishment clause concerns. The establishment clause concerns might present compelling state interest and justify prohibiting the groups. See, e.g., Bender v. Williamsport Area School Dist., 741 F.2d 538, 559 (3d Cir. 1984), cert. grantcd, 105 S. Ct. 1167 (1985).

96. See supra note 61 and accompanying text.

97. See Fraser, 755 F.2d at 1361 n.5.

98. 438 U.S. $726,740-41$ (1978) (Court failed to create new categorical proscription of indecent speech).

99. See Fraser, 755 F.2d at 1363-65.

100. Id. at 1365 . 
concluded that the school created a limited public forum ${ }^{101}$ and that it failed to demonstrate a compelling state interest, such as material and substantial disruption, that would justify prohibiting the speech.

\section{Time, Place, and Manner Regulations.}

The court of appeals apparently beheved that the school administrators did create a limited public forum, yet it ignored the fact that the Supreme Court has declared that, in any type of forum, the goverument can impose reasonable time, place, and manner regulations. ${ }^{102}$ In Tinker, the Court even recognized that school authorities could impose reasonable regulations of speech. ${ }^{103}$ To justify a restriction on speech as

101. It is not clear exactly what the Ninth Circuit meant by "open forum." Id. The court failed to cite any authority. The Supreme Court, however, apparently used the term "open forum" in Widmar v. Vincent, 454 U.S. 263, 275 (1981), to mean a limited public forum. In Widmar, the Supreme Court determined that the public university created a limited public forum in its meeting facilities; therefore, the umiversity could not deny access to a student religion club that sought to use these facilities. Id. at 267 n.5. The Court did not address the question whether Widmar applied in the secondary school context but noted that university students "are less impressionable than younger students." See id. at 274 n.14. Lower federal courts, however, have interpreted the term "open forum" in the elementary and secondary school contexts to refer to a school's creation of a limited public forum. See, e.g., Student Coalition for Peace v. Lower Merion School Dist. Bd. of School Directors, 776 F.2d 431, 436 (3d Cir. 1985) (school board did not create limited open forum in school athletic facilities by intermittently allowing certain organizations such as the Special Olympics to use the facilities; therefore, board did not violate first amendment when it denied use of facilities to Student Coalition for Peace, who wished to hold a peace fair); Bell v. Littlc Axe Indep. School Dist. No. 70, 766 F.2d 1391, 1399-402 (10th Cir. 1985) (school district created limited open forum in its elementary school by adopting equal access policy for all student groups who wished to use school facilities); Bender v. Willianısport Area School Dist., 741 F.2d 538, 547-49 (3d Cir. 1984), cert. granted, 105 S. Ct. 1167 (1985) (high school could create a limited open forum during its club activity period just as university in Widmar created hmited open forum); Kuhlmeier v. Hazelwood School Dist., 607 F. Supp. 1450, 1463 (E.D. Mo. 1985) (school officials who create open forum for student expression, such as school newspaper, are greatly limited in their ability to restrain or silence student expression based on inessage's content); Clergy \& Laity Concerned v. Chicago Bd. of Educ., 586 F. Supp. 1408, 1411-13 (N.D. Ill. 1984) (high school created limited open forum by allowing military recruiters to speak at high school; therefore, school must have compelling state interest to deny access to peace activist group that wished to speak).

Congress has also used the term "open forum" in the Equal Access Act, 20 U.S.C.A. $\$ \S 4071$ 72 (West Supp. 1985). The Act was adopted to extend to secondary schools the constitutional principle adopted by the Supreme Court in the university context in Widmar, 454 U.S. at 267 n.5. See S. REP. No. 357, 98th Cong., 2d Sess. 29, reprinted in 1984 U.S. CoDE CoNG. \& AD. NEws 2348, 2375; 130 Cong. Rec. $\mathbf{S 3 5 5}$ (daily ed. June 27, 1984) (remarks of Sen. Levin); $i d$. at S8357 (remarks of Sen. Durenburger). Congress announced that "[a] public secondary school has [created] a limited open forum whenever such school grants an offering to or opportunity for one or more noncurriculum related student groups to meet on school premises during noninstructional time." Equal Access Act, 20 U.S.C.A. $\$ 4071$ (b) (West Supp. 1985). Noninstructional time is defined as "time set aside by the school before actual classroom instruction begins or after actual classroom instruction cnds." Id. § 4072(4).

102. See supra notes 71-75 and accompanying text.

103. See Tinker, 393 U.S. at 513 ("We properly read [the Constitution] to permit reasonable regulation of speech-connected activities in carefully restricted circumstances."). 
a reasonable time, place, and manner regulation, the government must demonstrate that the regulation (1) is content-neutral, (2) serves a substantial and legitimate governmental interest, and (3) leaves open adequate alternative channels of commumcation. ${ }^{104}$ The school regulation challenged in Fraser is a vahd time, place, and manner regulation.

1. Content Neutrality: The Captive Juvenile Audience Exception. The content-neutrality requirement appears at first to defeat any attempt to justify the regulation of Fraser's speech as a reasonable time, place, and manner restriction. Members of the Supreme Court have, however, recognized that tinne, place, and manner regulations need not be contentneutral when either a captive audience or a juvenile audience is present. ${ }^{105}$ In FCC v. Pacifica Foundation, the Court upheld the FCC's declaratory order that a radio station that broadcast George Carlin's "Filthy Words" monologue could be subject to administrative sanctions because, in part, the afternoon broadcast was uniquely accessible to children. ${ }^{106}$ In Lehman v. City of Shaker Heights, ${ }^{107}$ the Court sustained a municipal ordinance prohibitmg political advertising on sigus withm buses because the bus riders constituted a captive audience. 108 Since the higli school assembly audience in Fraser was both a captive and juvenile audience, punishment of Fraser sliould fall withm the content-neutrality exception. 109

2. The School's Substantial and Legitimate Interest. The significant governmental interest at stake in Fraser is, in essence, that of protecting school children from indecent speech. The interest, however, consists of three interrelated factors: first, the school's interest in protecting students in a captive audience from vulgar and indecent speech; ${ }^{10}$ second, the school's interest in controlling tlie use of indecent

104. See supra notes $71-75$ and accompanying text.

105. See Young v. American Mini Theaters, 427 U.S. 50, $85-86$ (1976) (Stewart, J., dissenting, joined by Marshall, Brennan, and Blackmun, J.J.) (recognizing that time, place, and manner regulations need not be content-neutral in the context of a captive or juvenile audience); see also L. TRIBE, American Constiturion, 672-73 (1978); Farber, Content Regulation and the First Amendment: $A$ Revisionist View, 68 GEO. L.J. 727, 733 n.33 (1980).

106. FCC v. Pacifica Found., 438 U.S. 726, 729-30, 749 (1978); see Ginsberg v. New York, 390 U.S. 629,643 (1968) (sustaining New York statute forbidding sale of pornographic magazines to children).

107. 418 U.S. 298 (1974) (plurality opinion).

108. Id. at 302 .

109. See also infra notes 113-23 and accompanying text.

110. See Board of Educ. v. Pico, 457 U.S. 853, 871 (1982) (plurality opinion) (state can legitimately remove books that are pervasively vulgar); Pacifica Found., 438 U.S. at 749-50; Ginsberg v. New York, 390 U.S. 629, 638-39 (1968); see also infra notes 113-23 and accompanying text. 
speech at a school function; ${ }^{111}$ third, the school's interest in inculcating values, which permits it to prevent vulgar and indecent speech at a school assembly. ${ }^{112}$

a. Public school children at an assembly as a captive audience. The first amendment presupposes a willing listener and a willing speaker. ${ }^{113}$ A person in a captive audience, however, does not have the opportunity to choose to listen or not to listen to offensive speech. If a person is in a captive audience and subjected to offensive speech, the government may prohibit the offensive speech without abridging the speaker's first amendment rights. ${ }^{114}$

In Public Utilities Commission v. Pollak, ${ }^{115}$ Justice Douglas, in dissent, argued that the first amendment should preclude the Public Utilities Commission from piping music into streetcars because the streetcar riders were a captive audience. Justice Douglas argued that "the inan in the streetcar has no choice but to sit and histen, or perhaps to sit and try not to histen."116 Justice Douglas rejected the contention that because streetcar riders choose to ride in the streetcar they are not a captive audience: "[I]n a practical sense [streetcar riders] are forced to ride" because they have no alternative. 117

In Lehman v. City of Shaker Heights, ${ }^{118}$ the Court accepted Justice Douglas's view that streetcar riders are a captive audience. The Court rejected the petitioner's claim that Shaker Heiglits abridged his first amendment rights by prohibiting all political advertising on its buses. ${ }^{119}$ Justice Douglas, concurring, emphasized the commuters' constitutional rights: "While petitioner clearly has a right to express his view to those who wish to listen, he has no right to force his message upon an audience

111. See infra notes $124-42$ and accompanying text.

112. See infra notes 143-56 and accompanying text.

113. See Heffron v. International Soc'y for Krishna Consciousness, 452 U.S. 640,655 (1981) (first amendment "protects the right of every citizen to 'reach the minds of willing listeners" "); Virgina State Bd. of Pharmacy v. Virginia Citizens Consumer Council, 425 U.S. 748, 756 (1976) ("Freedom of speech presupposes a willing speaker."); Pell v. Procunier, 417 U.S. 817, 822 (1974) ("[F]ree speech includes a right to communicate a person's views to any willing listener . . . .").

114. See Bolger v. Youngs Drug Prods. Corp., 463 U.S. 60, 72 n.25 (1983); Consolidated Edison Co. v. Public Serv. Comm'n, 447 U.S. 530, 541-42 (1980); Lehman v. City of Shaker Heights, 418 U.S. 298, 306-07 (1974) (Douglas, J., concurring); Rosenfield v. New Jersey, 408 U.S. 901 (1972) (Burger, C.J., dissenting), denying cert. to 59 N.J. 435, 283 A.2d 535 (1971); NLRB v. United Steelworkers, 357 U.S. 357, 368 (1958) (Warren, C.J., concurring in part and dissenting in part).

115. 343 U.S. 451 (1952).

116. Id. at 469 (Douglas, J., dissenting) (emphasis in original).

117. Id. at 468 .

118. 418 U.S. 298, 302 (1974).

119. Id. at 302-03. The Court has since classified Lehman as a case where the card space on the public transportation system is a nonpublic forum. See, e.g., Perry Educ. Ass'n v. Perry Local Educators' Ass'n, 460 U.S. 37, 47 (1983). 
incapable of declining to receive it." 120

Students at the high school assembly, like streetcar riders, are a captive audience. ${ }^{121}$ Laws require the students to attend school daily. The scliool adninistrators plan many events as part of the curriculuni, including events in the school auditoriunt. Once inside the school auditorium, the students cannot walk away from indecent and vulgar speech. ${ }^{122}$ The students at the assembly have no choice "but to sit and listen, or perhaps to sit and try not to histen." 123

\section{b. Minors exposed to indecent speech at an event that is part of the} curriculum. The second aspect of the scliool's substantial and legitimate interest is its interest $\mathrm{m}$ regulating indecent and vulgar speech at an organized scliool assenibly. The Supreme Court has recognized that states have a legitimate interest in protectimg juveniles from indecent speecl ${ }^{124}$ and that scliool authorities can control offensive speech that is presented as part of the curriculum. ${ }^{125}$

FCC v. Pacifica Foundation demonstrates that the Supreme Court will uphold restrictions on a broadcast's indecent content in order to pro-

120. Lehman, 418 U.S. at 307 (Douglas, J., concurring).

121. See, e.g., Lubbock Civil Liberties Union v. Lubbock Indep. School Dist., 669 F.2d 1038, 1046 (5th Cir. 1982), cert. denied, 459 U.S. 1155 (1983); Brandon v. Board of Educ., 635 F.2d 971, 978 (2d Cir. 1980), cert denied, 454 U.S. 1123 (1981); Thomas v. Board of Educ., 607 F.2d 1043, 1049 (2d Cir. 1979), cert. denied, 444 U.S. 1081 (1980); East Hartford Educ. Ass'n v. Board of Educ., 562 F.2d 838, 851 (2d Cir. 1977); Meltzer v. Board of Pub. Instruction, 548 F.2d 559, 574 (5th Cir.), cert. denied, 439 U.S. 1089 (1977); Katz v. McAulay, 438 F.2d 1058, 1061 (2d Cir. 1971), cert. denied, 405 U.S. 933 (1972); Egner v. Texas City Indep. School Dist., 338 F. Supp. 931, 944 (S.D. Tex. 1972); Mailloux v. Kiley, 323 F. Supp. 1387, 1392 (D. Mass.), affd, 448 F.2d 1242 (1st Cir. 1971); see also Black, He Cannot Choose But Hear: The Plight of the Captive Auditor, 53 Colum. L. Rev. 960, 969 n.18 (1953); Diamond, supra note 26, at 493. But see Ganibino v. Fairfax County School Bd., 564 F.2d 157, 158 (4th Cir. 1977) (per curiam).

122. Fraser argued that students at Bethel High School were free to walk out of the assembly at any tinie. See Brief of Respondent's In Opposition to Certiorari at 5-6, Fraser v. Bethel School Dist., $106 \mathrm{~S}$. Ct. 56 (1985). But because of the length of the speech, it would have been physically inipossible for students to leave upon hearing the offensive speech. See supra note 48 (text of speech).

123. Pollak, 343 U.S. at 307 (Douglas, J., dissenting) (entphasis in original).

124. See supra note 110 and acconipanying text.

125. See Board of Educ. v. Pico, 457 U.S. 853, 864 (1982) (school authorities nust be allowed to establish and apply their curriculun in a way that transnits local community values; so long as school authorities are not seeking to suppress the ideas presented in textbooks, they nray remove books fron the school library that are pervasively vulgar).

The lower federal courts have also examined whether or not a student activity was part of the curriculum in order to determine whether the school authorities could prohibit offensive and vulgar speech. See Seyfried v. Walton, 668 F.2d 214, 216 (3d Cir. 1981) ("crucial factor in this case is the relationship of the play to the school curriculum"); Gambino v. Fairfax County School Bd., 564 F.2d 157, 158 (4th Cir. 1977) (per curiam) (student newspaper not part of the school curricuium); Kuhlmeier v. Hazelwood School Dist., 607 F. Supp. 1450, 1465 (E.D. Mo. 1984) (school newspaper part of school curriculum). 
tect children.126 The Supreme Court presented the following four reasons for allowing the FCC to prohibit the afternoon broadcast of George Carhin's "Filthy Words" monologue: (1) that the patently offensive and indecent speech confronted the citizen in his own home; (2) that children could easily gain access to the indecent speech; (3) that the indecent speech abridged the primary caretaker's responsibility for the care of the children; (4) that the state's independent interest in the well-being of its youth justified restricting a minor's access to indecent speech. ${ }^{127}$ The four rationales presented in Pacifica Foundation also apply to the high school assembly and support the argument that the school has a legitimate and substantial interest in protecting children from indecent speech at a school assembly.

Pacifica Foundation's first rationale was that the patently offensive and indecent speech confronted the citizen in his home. Obviously the offensive language presented at a school assembly does not confront the children in their homes, yet the children at the high school assembly constitute a captive audience. ${ }^{128}$ The privacy imterests that allow a citizen to prevent offensive material from coming into his home ${ }^{129}$ should also apply to school children in a captive audience at a school assembly. 130

126. See Pacifica Found., 438 U.S. 726, 749-50.

127. In Pacifica Foundation the Court rested its decision on several premises: (1) the fact that indecent speech confronted the citizen in the privacy of his home, id. at 748; (2) the fact that the broadcasts were "uniquely accessible to children," $i d$. at 749; and (3) the relevance of "the concerns recognized in Ginsberg," id. at 750. The Court in Ginsberg v. New York recognized two concerns, see 390 U.S. 629, 636 (1968); therefore, Pacifica Foundation has been treated as having four rationalcs.

In Ginsberg, the Supreme Court upheld a state statute prohibiting merchants from selling pornographic magazines to children under 17. The Court based its decision on two concerns. First, the Court justified the statute as promoting the parents' claim of authority to direct the rearing of their children and to look out for the child's well-being. Id. at 639. Second, the Court recognized that the State itself has an independent interest in the well-being of its youth. Id. at 640-41.

128. See supra notes 113-23 and accoinpanying text.

129. See Rowan v. United States Post Office Dep't, 397 U.S. 728 (1970). In Rowan the Supreme Court sustained a federal statute that permitted recipients of unsolicited mail advertisennents to havc the Postal Service order the advertiser to stop the mailings if the recipients believed the inaterials to be erotically arousing or sexually provocative. Id. at 740. The Court rested its decision on the citizen's privacy interest while in his hoine. The Court stated: "That we are often 'captives' outside the sanctuary of the home and subject to objectionable speech and other sound does not inean we must be captives everywhere." Id. at 738.

130. In Rowan v. United States Post Office Dep't, id. at 738, the Court cited Public Util. Comm'n v. Pollak, 343 U.S. 451 (1951), to support its argument that a citizen is often a "captive" outside the sanctuary of his home in the sense that he will be unable to avoid being subjected to objectionable speech. In Pollak the Court rejected Justice Douglas's argument that the first amendment protects the privacy rights of a person in a captive audience. Pollak, 343 U.S. at 464. Thus, it would appear that a person in a captive audience outside his home would not have a sufficient privacy interest to justify a restriction on offensive speech. In Lehman v. City of Shaker Heights, 418 U.S. 298, 302-04 (1974) (plurality opinion), however, the Court accepted Justice Douglas's view 
The second rationale advanced by the Pacifica Court for prohibiting Carlin's monologue was the "ease with which children can obtain access to broadcast material."131 Children could simply turn on the radio during the afternoon and be subjected to indecent and offensive language. Pacifica's second rationale apphes to the high school assembly. A student is either forced to attend the asseinbly or chooses to attend, but in either case the child has easy access to the assembly. ${ }^{132}$ Once the child hears the offensive speech at the asseinbly, the damage has been done. To say that the child could avoid further offense by "tuning out" the speaker "is like saying that the reinedy for an assault is to run away after the first blow."133

Pacifica Foundation's third rationale for prohibiting Carlin's monologue was that the indecent speech conflicted with the parents' authority to direct and rear the child. The Court's concern, however, was not limited to the parents' authority because the Court, in Ginsberg v. New York, upon which the Pacifica Foundation Court rehed, had stated that "parents and others, teachers, for example, who have [the] primary responsibility for children's well-being are entitled to the [law's] support."134 Thus, the Court has recognized that parents and teachers have a responsibility to protect children from offensive and indecent speech.

Finally, Pacifica Foundation's fourth rationale was that the state's independent interest in the well-being of its youth justified limiting minors' access to indecent speecli. ${ }^{135}$ The Court recognized that the state has an interest in protecting children's welfare to ensure that they are

that the person on a streetcar was a captive audience and did have a sufficient privacy interest to justify a governmental restriction on speech.

131. Pacifica Found., 438 U.S. at 750.

132. The court of appeals in Fraser found it significant that the students were given a choice between attending the assembly or attending a study hall. Fraser, 755 F.2d at 1364. It is important to remember, however, that "[t]he law of imitation operates, and nonconformity is not an outstanding characteristic of children." McCollum v. Board of Educ., 333 U.S. 203, 227 (1948) (Frankfurter, J., concurring). Thus, an "alternative" might be illusory.

133. Pacifica Found., 438 U.S. at 748-49. The court of appeals in Fraser rejected this rationale in the high school context because the court thought that the Supreme Court in Pacifica Foundation was only concerned with children too young to read. Fraser v. Bethel School Dist., 755 F.2d 1356, 1362-63 (9th Cir. 1985). The Fraser court, however, ignored the fact that in Pacifica Foundation the child involved was 15 years old. See WBAI ruling: Supreme Court saves the worst for last, BROADCAsting, July 10, 1978, at 20. Furthermore, in Pacifica Foundation the Court stated that "broadcasting is uniquely accessible to children, even those too young to read," Pacifica Found., 438 U.S. at 749 , which means that the Court was concerned primarily but not exclusively with children too young to read.

134. Ginsberg v. New York, 390 U.S. 629, 639 (1968) (emphasis supplied); cf. Goss v. Lopez, 419 U.S. 565, 594 (1975) (Powell, J., dissenting) (footnote omitted) ("[T] he teacher must occupy many roles-educator, adviser, friend, and, at times, parent-substitute.").

135. Ginsberg v. New York, 390 U.S. 629, 640 (1968) (quoting People v. Kaham, 15 N.Y.2d 311, 312, 206 N.E.2d 333, 334 (1965) (Fuld, J., concurring)). 
"safeguarded from abuses,"136 including the abuse of indecent speech. The state's interest is even stronger in the school environment at an assembly that is part of the curriculum.

The school assembly in Fraser was part of the school curriculuin. ${ }^{137}$ The Supreme Court has recognized that high school authorities must be able to plan their school curriculum in such a way as to transinit local and community values. ${ }^{138}$ The school administrators allowed the students to have the assembly in order to teach rhetoric and leadership in the process of electing the student government. ${ }^{139}$ The State of Washington expressly subjects each public high school student government to regulation: Student body governments are "formal organization[s] of the students of a school formed with the approval of and regulation by the board of directors of the school district." ${ }^{140}$ The school administrators did not give the student an "absolute constitutional right to use [the] . . . school [asseinbly] . . . for his unlimited expressive purposes."141 It is implausible to argue that a student should be able to say anything at a school assembly so long as it is not obscene or does not materially and substantially disrupt the school environinent. ${ }^{142}$

136. Id. (quoting Prince v. Massachusetts, 321 U.S. 158, 165 (1944)).

137. Although the assembly is not part of the classroom curriculum, lower federal courts have recognized that non-classroom activities can also be part of the school curriculum. See Seyfried v. Walton, 668 F.2d 214, 216 (3d Cir. 1981) (school play); ABC League v. Missouri State High School Activities Ass'n, 530 F. Supp. 1033, 1040 (E.D. Mo. 1981) (interscholastic athletics), rev'd, 682 F.2d 147 (1982); Matute v. Carson Long Inst., 160 F. Supp. 827, 828 (M.D. Pa. 1958) (varsity football program); $c f$. WEBSTER's THIRD NEW INTERNATIONAL D1CTIONARY 557 (1981) (defining "curriculum" as "all planned school activities including besides courses of study organized play, athletics, dramatics, clubs, and hoine-room program[s]").

138. See Board of Educ. v. Pico, 457 U.S. 853, 864 (1982) (school boards must be pernitted "to establish and apply their curriculum in such a way as to transmit community values").

139. See Fraser, 755 F.2d at 1367 (Wright, J., dissenting).

140. WASH. REV. CODE ANN. § 28A-58.115 (Supp. 1986).

141. Grayned v. City of Rockford, 408 U.S. 104, 116 (1972).

142. For example, racially or religiously inflammatory speech at a school assembly might not be disruptive, but it is incompatible with the assembly. Several writers have suggested that racially or religiously inflammatory speech in the school setting should be subject to strict controls due to the age and captivity of the audience. See, e.g., Juvenile Justice Standards Project, Institute of Judicial administration, \& American Bar association, Standards Relating to SCHOOLS AND EDUCATION, at 84-91 (tent. draft 1977) (4.2C and commentary); Berkman, Students in Court: Free Speech and the Functions of Schooling in America, 40 HARV. EDUC. REv. 567 (1970); Garvey, Children and the First Amendment, 57 TEX. L. REv. 321, 363-64 (1979); Gyory, The Constitutional Rights of Public School Pupils, 40 FORDHAM L. REV. 201, 216-19 (1971).

Moreover, despite language in Tinker to the contrary, 393 U.S. at 511 (students both in and out of school are, under our Constitution, "persons" possessing fundamental rights), the constitutional rights of minors are not coextensive with those of adults. See Erznoznik v. City of Jacksonville, 422 U.S. 205, $214 \&$ n.11 (1975) (striking down as overbroad ordinance aimed at prohibiting minors from viewing any filn containing nudity); Tinker, 393 U.S. at 514-15 (Stewart, J., concurring) (first amendment rights of minors are not coextensive with those of adults); Ginsberg v. New York, 390 
c. The school's role in inculcating community values. The third aspect of the school's legitimate and substantial interest is the fact that allowing indecent and vulgar speech at a school assenbly is not consistent with the school's role in inculcating community values. The Supreine Court, ${ }^{143}$ lower federal courts, ${ }^{144}$ and commentators ${ }^{145}$ have recognized that public high school authorities are responsible not only for educating children but also for inculcating social values. The duty to inculcate community values includes the duty to condemn and discourage the usc of indecent speech. ${ }^{146}$ The school's failure to condemn indecent speech at a school asseinbly violates this duty and inay be interpreted as approval. ${ }^{147}$

U.S. 629, 649-50 (1968) (Stewart, J., concurring) (in certain areas, a child does not possess the full capacity for individual choice that the first amendinent presupposes).

A minor's constitutional right to privacy in abortion and birth control decisions is not coextensive with that of adults. See H.L. v. Matheson, 450 U.S. 398, $408-09$ (1981); Bellotti v. Baird, 443 U.S. 622, 634-37 (1979) (a state has greater authority to enact laws affecting minors deciding whether to have abortions than to enact laws affecting adults in same situation because of minor's lesser capacity for mature, affirmative choice); Carey v. Population Servs. Int'l, 431 U.S. 678, 693 \& n.15 (1977) (state restrictions inhibiting privacy rights of minors are valid if they serve any "significant state interest" that is not present in the case of adult, and "significant state interest" standard is less rigorous than "compelling state interest" test applied to restrictions on privacy rights of adults).

Minors are, however, entitled to coextensive rights when they are defendants in criminal proceedings. See Breed v. Jones, 421 U.S. 519, 541 (1975) (prohibition of double jeopardy); In re Winship, 397 U.S. 358, 368 (1970) (requirement of proof beyond a reasonable doubt); In re Gault, 387 U.S. 1, 33, 35, 47, $56-57$ (1967) (rights to notice, counsel, confrontation and cross-examination, and privilege against self-imcrimination); Gallegos v. Colorado, 370 U.S. 49, 54-55 (1962) (protection against the use of coereed confessions).

The constitutional riglts of minors are particularly circumscribed in a public school setting. $C f$. New Jersey v. T.L.O., $105 \mathrm{~S}$. Ct. 733, $742-43$ (1985) (probable cause not required in school searches because students have a lesser expectation of privacy than in nonschool setting); Ingraham v. Wright, 430 U.S. 651, 664 (1977) (cruel and unusual punishınent clause of eighth amendment does not apply to corporal punishment in public secondary schools).

143. See Board of Educ. v. Pico, 457 U.S. 853, 864 (1982); Ambach v. Norwick, 441 U.S. 68, 77 (1979).

144. See, e.g., East Hartford Educ. Ass'n v. Board of Educ., 562 F.2d 838, 843 (2d Cir. 1977).

145. See, e.g., Denno, Mary Beth Tinker Takes the Constitution to School, 38 Fordham L. Rev. 35, 51 (1969); Diamond, supra note 26, at 499-501; Garvey, supra note 142, at 373.

146. See Seyfried v. Walton, 668 F.2d 214, 220 (3d Cir. 1981) (Roseun, J., concurring) (great deference should be accorded school authorities when they prohibit material because of overt sexual references or vulgarity); Thomas v. Board of Educ., 607 F.2d 1043, 1057 (2d Cir. 1979) (Newman, J., concurring in result) ("[W]hether a school condennns or tolerates indecent language within its sphere of authority will have significance for the future of that school and of its students."), cert. denied, 441 U.S. 1081 (1980); Haskell, Student Expression in the Public Schools: Tinker Distinguished, 59 GEo. L.J. 37, 56 (1970). Cf. supra note 142 and accompanying text (discussing racially inflammatory speech).

147. See, e.g., Seyfried v. Walton, 688 F.2d 214, 216 (3d Cir. 1981); Webb v. Lake Mills Community School Dist., 344 F. Supp. 791,802 (N.D. Iowa 1972). 
The Ninth Circuit did not believe that the school's role in inculcating community values permitted it to apply an indecency standard to the high school student's speech. The court of appeals stated:

We fear that if school officials had the unbridled discretion to apply a standard as subjective and elusive as "indecency" in controlling the speech of high school students, it would increase the risk of cementing white, middle-class standards for determining what is acceptable and proper speech and behavior in our public schools. ${ }^{148}$

The Ninth Circuit's fear is unfounded and ignores the role local school boards, principals, teachers and parents play in educating the nation's children.

"School boards are uniquely local and democratic institutions."149 School board members are elected to educate the nation's youth during the latter's most formative and impressionable years. ${ }^{150}$ Elections to 10cal school boards are often hotly contested and present the electorate with wide-ranging ideological choices. ${ }^{51}$ Once elected, the school board, through parent-teacher organzations, is more informed and aware of the community's values than any other governmental agency. ${ }^{152}$ Thus, there is no reason to beheve that the values imparted to school children will be other than those held by the particular community in which the school is located; and if the school board and the adininistrators it hires are "cementing white, middle-class standards," 153 or any standards for that matter, through the use of unconstitutional restrictions on speech, the board is answerable to the electorate and to the federal judiciary. The members of the Supreme Court have recognized the importance of education, ${ }^{154}$ the school board's democratic nature, ${ }^{155}$ and its accountability resulting from close comniumity supervision of the nation's public schools. ${ }^{156}$ Courts should not disregard the school's role in inculcating

148. Fraser, 755 F.2d at 1363 .

149. Board of Educ. v. Pico, 457 U.S. 853, 894 (1982) (Powell, J., dissenting); see Diamond, supra note 26, at 509 .

150. See Board of Educ. v. Pico, 457 U.S. 853, 894 (1982) (Powell, J., dissenting).

151. See Diamond, supra note 26, at 509.

152. See Board of Educ. v. Pico, 457 U.S. 853, 894 (1982) (Powell, J., dissenting).

153. Fraser, 755 F.2d at 1363.

154. See, e.g., San Antonio Indep. School Dist. v. Rodriguez, 411 U.S. 1, 35 (1973) (recognizing the "undisputed importance of education"); Wisconsin v. Yoder, 406 U.S. 205, 221 (1972) ("[E]ducation prepares individuals to be self-reliant and self-sufficient participants in society."); Brown v. Board of Edue., 347 U.S. 483, 493 (1954) ("education is perhaps the most important function" of government).

155. See supra notes $149-52$ and accompanying text.

156. See, e.g., New Jersey v. T.L.O., 105 S. Ct. 733, 748 (1985) (Powell, J., concurring) (community provides substantial protection against violation of constitutional rights by school authorities); Ingraham v. Wright, 430 U.S. 651,670 (1977) (refusing to extend eighth amendment protcction to public secondary schools because of community supervision of schools). 
community values and the unique ability of the school board to conduct this task merely because of an unsubstantiated fear that by disciphining students for using sexually vulgar and indecent speech they will cement white middle-class values.

\section{Alternative Channels of Communication. When the Court has} upheld the use of time, place, and manner regulations to ban speech it has eniphasized the need for alternative channels of communication. ${ }^{157}$ In Fraser, alternative channels of communication are present. The student who wishes to use indecent and vulgar speech can do so after school or in a situation where the listeners voluntarily accept suclı speech. A contrary arguinent, lowever, is suggested by Schneider v. State. ${ }^{158}$ There the Court stated tliat "one is not to liave the exercise of his liberty of expression in appropriate places abridged on the plea tliat it niay be exercised in sonie other place."159 In Schneider, tlie Court rejected tlie argument that a city ordinance prohibiting distribution of leaflets on streets and alleys could be justified on the grounds that the leaflets could be distributed elsewliere. ${ }^{160}$ The weakness of this argunient is that the school assenibly is not the "appropriate place" for indecent speech. In fact, indecent speeclı is "basically inconipatible" with tlie scliool assembly.

The Suprenie Court first focused on the question of "basic incon1patibility" in Grayned v. City of Rockford, ${ }^{161}$ where the Court was faced

157. See supra note 74 and accompanying text. Compare Heffron v. International Soc'y for Krishna Consciousness, 452 U.S. 640, 654-55 (1981) (finding sufficient alternative channels of communication left open by the statute to sustain it as a reasonable time, place, and manner regulation) with Linmark Associates, Inc. v. Township of Willingboro, 431 U.S. 85, 93 (1977) (town ordinance prohibiting posting of "For Sale" or "Sold" signs failed to leave open ample alternative channels of communication since only alternative channels were listing house with real estate agent or using newspaper advertising, each of which cost significant amount of money) and Metromedia, Inc. v. City of San Diego, 453 U.S. 490, 516-17 (1981) (city ordinance imposing substantial prohibitions on off-premises outdoor noncommercial advertising display signs fails to leave open ample alternative channels of communication because other forms of advertising are insufficient, inappropriate, and prohibitively expensive).

158. 308 U.S. 147 (1939).

159. Id. at 163.

160. Id.

161. 408 U.S. 104 (1972). Since Grayned v. City of Rockford, members of the Court have used the "basic incompatibility" language seven times to assess both time, place, and manner regulations and public forum cases. See United States v. Grace, 461 U.S. 171, 185 (1983) (Marshall, J., dissenting) (passing out leaflets on steps of Supreme Court is not "basically incompatible" with normal sidewalk activity); Perry Educ. Ass'n v. Perry Local Educators' Ass'n, 460 U.S. 37, 63 n.7 (1983) (Brennan, J., dissenting) (granting outsiders access to school mailboxes is not "basically incompatible" with the school's normal activity); United States Postal Serv. v. Council of Greenburgh Civic Ass'ns, 453 U.S. 114, 130 n.6 (1981) (civic associations' practice of delivering messages to local residents by placing unstamped notices in residential mailboxes is "basically incompatible" with the maintenance of a safe and efficient national mail system); Heffron v. Interuational Soc'y for Krishna 
with the question whether Rockford's anti-noise ordinance was overbroad. The ordinance prohibited people on public or private property adjacent to a school building froin inaking noise that would disturb the school while it was in session. ${ }^{162}$ The petitioners clained that Rockford's anti-noise ordinance interfered with their first and fourteenth amendinent right to picket on a public sidewalk near a school. The Court analyzed Rockford's ordmance to determine whether it was a valid time, place, and inanner regulation. The Court stated: "The nature of a place, 'the pattern of its normal activities, dictate the kinds of regulations of time, place, and inanner that are reasonable' . . . The crucial question is whether the inanner of expression is basically incoinpatible with the normal activity of a particular place at a particular time."163 The Court noted that the touchstone of its analysis was Tinker, and said: "[W]e nowhere suggested [in Tinker] that students, teachers, or anyone else has an absolute constitutional right to use all parts of a school building or its immediate environs for his unlimited expressive purposes." 164

While the Court in Tinker did not expressly state that it was exainining the school children's speech for basic incompatibility with the school environment, an examination of the decision shows that it was. In Tinker the Court balanced the students' right to freedom of expression against the school administrators' need for discipline and control in the school. ${ }^{165}$ The Court recognized that it had to apply the students' first amendment rights "in light of the special characteristics of the school environment" 166 and announced the material and substantial disruption

Consciousness, 452 U.S. 640, 658 n.2 (1981) (Brennan, J., concurring in part and dissenting in part) (rejecting argument that the respondents' desire to distribute literature and solicit funds was "basically incompatible" with the normal activity of the fair); Schad v. Borough of Mount Ephraim, 452 U.S. 61, 74-75 (1981) (initial question in determining validity of city ordinance prohibiting all live commercial entertainunent as a tiune, place, and manner regulation was whether live entertainment was "basically incompatible" with the normal activity in commercial areas); Carey v. Brown, 447 U.S. 455, 482-83 (1980) (Rehnquist, J., dissenting) (arguing that a city ordinance that prohibited residential picketing was a reasonable time, place, and inanner restriction because residential picketing was "basically incompatible" with the normal activity in one's home); Greer v. Spock, 424 U.S. 828, 842-43 (1976) (Powell, J., concurring) (political rallies are "basically incompatible" with the normal activity of a military base).

162. Grayned, 408 U.S. at 105-08, 114.

163. Id. at 116 (quoting Wright, The Constitution on the Campus, 22 VAND. L. REv. 1027, 1042 (1969)).

164. Id. at 117-18.

165. See Tinker, 393 U.S. at 505-07. "First Anendment rights, applied in light of the special characteristics of the school environment, are available to teachers and students." Id. at 506. However, "the Court has repeatedly emphasized the need for affirming the comprehensive authority of the States and school officials." Id. at 507. "Our problem lies in the area where students in the exercise of First Amendment rights collide with the rules of school authorities." Id.; see also Denno, supra note 145, at 57; J. NowAK, R. RoTUNDA \& J. YouNG, supra note 75, at 991.

166. Tinker, 393 U.S. at 506. 
standard. ${ }^{167}$ Material and substantial disruption is "basically incoinpatible" with the school's purpose to educate children. ${ }^{168}$ Lower federal courts, including the Ninth Circuit in Fraser, have assumed that the only incompatibility between student speech and the school's purpose arises when the student's speech inaterially and substantially disrupts the school's operation. ${ }^{169}$ Some speech, however, that does not materially and substantially disrupt the school's operation can also be "basically incoinpatible" with the school's environment. 170

Thus, the school authorities can demonstrate that Fraser had alternative channels of communication available in which to express his thoughts indecently. The action of the school authorities, under current time, place, and manner analysis, was therefore not invalidated by arguments that a school asseinbly is an appropriate place in which to give an indecent speech.

167. Id. at $512-13$.

168. Cornelius v. NAACP Legal Defense \& Educ. Fund, 105 S. Ct. 3439, 3461 n.3 (1985) (Blackmun, J., dissenting) (Tinker requires showing of incompatibility).

169. See supra notes $32-50$ and accompanying text.

170. See supra note 142 and accompanying text.

In assessing the "compatibility" of indecent speech with the educational environment, it is important to distinguish a public university assembly from a public secondary or elementary school assembly. The public university's mission is education. The university can impose reasonable regulations compatible with that mission upon the use of its campus and facilities. See Widinar v. Vincent, 454 U.S. 263, 267 n.5, 270 (1980) (public university is limited public forum, at least for its students; therefore, state must show that regulation concerning speech is necessary to serve compelling state interest and that it is narrowly drawn to achieve that end). However, there exists within every university the means and facilities by which ideas may be presented and challenged through interactive discussion. The ideas presented in the active debate at a university assembly may offend some students. Nonetheless, the mere dissemination of offensive or indecent ideas at a university assembly should not be cut off in the name of "decency." See Papish v. Board of Curators, 410 U.S. 667, 670-71 (1973) (per curiam) (indecent political cartoon and profane headline in public university's paper held not obscene or unprotected). Generally speaking, indecent speech at a university assembly is not at all incompatible with the public university's mission or with the age and experience of its student body. It is highly unlikely that a university wonld ever have an asseinbly comparable to a high school assembly. Students in a university have a great deal more freedom in choosing whether or not to attend any public gathering or debate. Although the university could impose reasonable time, place, and manner regulations on any event taking place on campus, see supra notes 71-75 and accompanying text, the university could not use the captive juvenile audience exception in justifying those regulations. See supra notes 105-09 and accoinpanying text.

The educational mission of the public elementary and secondary schools is more circumscribed than that of the public university. See, e.g., Board of Educ. v. Pico, 457 U.S. 853, 914 (1982) (Rehnquist, J., dissenting) (distinguishing secondary schools from universities); Bender v. Williamsport Area School Dist., 741 F.2d 538, 547-48, 554 (3d Cir. 1984) (educational mission of ligh school is inore circuinscribed than that of university), cert. granted, $105 \mathrm{~S}$. Ct. 1167 (1985). The high school is inore structured and the students are less mature than those in a university. While the public university's mission and its assemblies are designed in part to provide a battleground for clashes between contending lines of tliouglit, the high school assembly has a nuch more limited scope and, therefore, has a lower threshold for speech that is basieally incompatible with the environment. 
4. Vagueness or Overbreadth. In order for the Court to sustain the school regulation as a valid time, place, and manner regulation, the school regulation must not be vague or overbroad. ${ }^{171}$ In conducting this assessment, it is important to remember that school disciplinary rules must be capable of addressing a myriad of circuinstances that require prompt and effective disciplinary action. ${ }^{172}$ Furthermore, school regulations are typically developed by local school boards with the participation of concerned parents, school officials, and members of the coinmunity, and reflect the community's expectations for socially acceptable conduct. ${ }^{173}$ Thus, school disciplinary regulations must be interpreted flexibly ${ }^{174}$ and must not be held to the criminal law's standards for vagueness and overbreadth. ${ }^{175}$ If the Ninth Circuit had interpreted the Bethel High School disciplinary regulation flexibly, ${ }^{176}$ the regulation would have withstood both vagueness and overbreadth challenges.

a. Vagueness. The Supreme Court has recognized that to withstand a vagueness challenge statutes written specifically for the school context need only to delineate their reach "in words of common understanding" and to be viewpoint-neutral. ${ }^{177}$ Bethel High School's regulation did not specifically prohibit the use of indecent speech at a school assembly; ${ }^{178}$ however, the regulation did prohibit "acts which disrupt and interfere with the educational process . . . including the use of ob-

171. See supra note 75 and accompanying text.

172. See New Jersey v. T.L.O., 105 S. Ct. 733, 743 (1985).

173. Cf. supra notes 149-56 and accompanying text (discussing role of school board and parents in formulating school policy in manner that inculcates community values).

174. See Esteban v. Central Missouri State College, 415 F.2d 1077, 1089-90 (8th Cir. 1969), cert. denied, 398 U.S. 965 (1970) (then-Circuit Judge Blackmun declaring that "flexibility and elbow room" must be given to school regulations); Whitfield v. Simpson, 312 F. Supp. 889 , 898 (E.D. III. 1970) (greater flexibility should be used in assessing regulations governing high school students than those governing college students beeause of differences in the range of activities subject to discipline and in the age of students); $c f$. New Jersey v. T.L.O., 105 S. Ct. 733, 743 (1985) ("[M]aintaining. . . order in the schools requires a certain degree of fexibility in school disciplinary procedures . . . .").

175. See, e.g., Black Coalition v. Portland School Dist. No. 1, 484 F.2d 1040, 1044 (9th Cir. 1973); Murray v. West Baton Rouge Parish School Bd., 472 F.2d 438, 442 (5th Cir. 1973); Sword v. Fox, 446 F.2d 1091, 1099 (4th Cir.), cert. denied, 404 U.S. 994 (1971); Esteban v. Central Missouri State College, 415 F.2d 1077, 1089-90 (8th Cir. 1969), cert. denied, 398 U.S. 965 (1970).

176. See Fraser, 755 F.2d at 1365 n.12. The court of appeals affirned the district court's ruling that the school's misconduct rule was unconstitutional because on its face it allowed school authorities to discipline students for using indecent speech in extracurricular activities. Although the district court's language is far from clear, see Petitioner's Brief at B-23, Fraser v. Bethel School Dist., 755 F.2d 1356 (9th Cir.), cert. granted, 106 S. Ct. 56 (1985), the district court apparently applied criminal vagueness and overbreadth requirements to the school regulation.

177. See Grayned v. City of Rockford, 408 U.S. 104, 112 (1972); see also supra notes 161-64 and accompanying text (discussing Grayned).

178. See supra note 47 and accompanying text. 
scene, profane language or gestures."179 Thus, the definition includes both acts and speech that disrupt and interfere with the education process. The overriding idea behind the school regulation, as denionstrated by its text, is the prohibition of speech or conduct that is basically niconipatible with the school environment. ${ }^{180}$ School administrators should not be expected to draft rules that specifically delineate each type of prohibited conduct or speech. ${ }^{181}$

In assessing the school regulation, it is also important to note that the school authorities did not seek to punish a student for the expression of an unpopular point of view. ${ }^{182}$ Matthew Fraser testified that he knowingly used "sexual innuendo" in his nominating speech. Fraser dehvered the speech to establish rapport with the students. ${ }^{183} \mathrm{He}$ wished to denionstrate that, like his candidate, he had the pohtical guts to stand up before the adniimstration and deliver a speech that some students would find witty but that the administration would find inappropriate. By den1onstrating that he and his candidate would stand up and dehver an offensive speech, Fraser wished to demonstrate that they were willing to take risks and face the adversary, the school administration. ${ }^{184}$

The school administrators, however, did not wish to suppress the idea ${ }^{185}$ that a student government officer would stand up and challenge the school administration. The school administration merely wished to regulate the form of the niessage in hight of the school assembly environnient. Justice Stevens has einphasized that "[g]overnmental suppression of a specific poimt of view strikes at the core of First Amendment values. In contrast, regulations of form and context may strike a constitutionally appropriate balance between the advocate's right to convey a message and the recipient's . . . environment."186 A requirement that indecent language be avoided will have its primary effect on the form, rather than the content of serious communication. There are few, if any, ideas which

179. Id.

180. See supra notes 161-70 and accompanying text (discussing the "basic incompatibility" rule used to assess time, place, and manner regulations); see also supra notes 174-76 and accompanying text (flexible interpretations of school regulations).

181. See supra note 175 and accompanying text.

182. See, e.g., Grayned v. City of Rockford, 408 U.S. 104, 113 (1972) ("Rockford's anti-noise ordinance does not permit pumshment for the expression of an unpopular point of view. . . .").

183. Fraser, 755 F.2d at 1363.

184. See Respondent's Brief in Support of Denial of Certiorari at 16, Fraser v. Bethel School Dist., 106 S. Ct. 56 (1985) (granting certiorari).

185. See Board of Educ. v. Pico, 457 U.S. 853, 871 (1982) (Constitution does not permit official suppression of ideas, yet school administrators can remove books that are not educationally suitable).

186. Bolger v. Youngs Drug Prods. Corp., 463 U.S. 60, 84 (1983) (Stevens, J., concurring) (footnote omitted). 
cannot be presented in an environmentally appropriate form. ${ }^{187}$

b. Overbreadth. A clear and precise enactment may be "overbroad" if in its reach it prohibits constitutionally protected speech. ${ }^{188}$ The Court disdams overbroad laws because such laws chill privileged speech. ${ }^{189}$ "The crucial question . . . is whether the [law] sweeps within its prohibitions what may not be punished under the First and Fourteenth Amendnients." 190 The school regulation does not.

In Grayned v. City of Rockford, ${ }^{191}$ persons arrested and convicted for violating Rockford's anti-picketing ordinance argued that the ordinance was overbroad. ${ }^{192}$ The Court rejected the overbreadth argument and sustained the regulation as a valid time, place, and inanner regulation. ${ }^{193}$ The Court noted that the touchstone of its analysis was Tinker ${ }^{194}$ and that the crucial question in assessing regulations of speech or conduct in the school context is whether the manner of expression prohibited is "basically incompatible with the normal activity of a particular place at a particular time." ${ }^{195}$ So long as the regulation does not sweep in speech or conduct that is compatible with the school environment, and therefore protected, such as the black armbands in Tinker, the ordimance should be sustained against an overbreadth challenge. 196

Thus, interpreting the school regulation flexibly in light of the school environment, it is evident that the regulation merely seeks to reach speech that is "incoinpatible with normal school activities," 197 a category which includes indecent speech communicated to a captive juvenile audience.

187. FCC v. Pacifica Found., 438 U.S. 726,743 n.18 (plurality) (opinion of Stevens, J.).

188. See, e.g., Grayned v. City of Rockford, 408 U.S. 104, 114 (1972); Zwickler v. Koota, 389 U.S. 241, 249-50 (1967) and cases cited therein.

189. See, eg., Grayned v. City of Rockford, 408 U.S. 104, 109 (1972).

190. Id. at 114-15.

191. Id. at 104.

192. Id. at 114. The city's anti-picketing ordinance provided:

A person commits disorderly conduct when he knowingly: (i) Pickets or demonstrates on a public way within 150 feet of any primary or secondary school building while the school is in session and one-half hour before the school is in session and one-half hour after the school session has been concluded ....

Id. at 107 (citation omitted).

193. Id. at 115 .

194. Id. at 117.

195. Id. at 116.

196. See id. at 117-18.

197. Id. at 120. 


\section{CONCLUSION}

For sixteen years the lower federal courts have assumed that Tinker's material and substantial disruption standard is dispositive on questions of secondary and elementary school student speech. The lower federal courts have failed to realize that Tinker actually is a public forum doctrine case in which the Court defined the public secondary and elementary schools as limited public forums. Accordingly, courts should employ traditional time, place, and maimer analysis in assessing the validity of school regulations concerning student speech. Because the Nintlı Circuit improperly read Tinker and thereby erroneously invalidated a school regulation that was a legitimate time, place, and manner restriction, Fraser v. Bethel School Distict offers the Supreme Court an opportunity to correct this sixteen-year-old misperception.

James C. Dever III 